\title{
QUALITATIVE AND QUANTITATIVE CHARACTERIZATION OF A COAL POWER PLANT WASTE BY TG/DSC/MS, XRF AND XRD
}

\author{
JOSEFA FERNÁNDEZ ${ }^{1 *}$, FERNANDO GONZÁLEZ ${ }^{1}$, CARMEN PESQUERA ${ }^{1}$, ALEX NEVES JUNIOR², \\ MARCELO MENDES VIANA ${ }^{3}$ AND JO DWECK ${ }^{3}$ \\ ${ }^{1}$ Department of Chemistry and Process and Resource Engineering, ETSIIyT, University of Cantabria, Santander, Spain \\ ${ }^{2}$ Architecture, Engineering and Technology Faculty, Mato Grosso Federal University, Cuiabá, Brazil \\ ${ }^{3}$ Department of Inorganic Processes, School of Chemistry, Federal University of Río de Janeiro, Rio de Janeiro, Brazil
}

\begin{abstract}
$\mathrm{SO}_{2}$ removal from coal-fired power plant flue gases can be done by dry, semi-dry or wet desulfurization processes, using limestone or lime containing products as sorbents. In a Brazilian coal power plant there is a dry desulfurization unit to capture $\mathrm{SO}_{2}$ with hydrated lime from the combustion gases. A part of the flying ashes produced is mixed with the bottom coal ashes and the spent sulphated product generated after $\mathrm{SO}_{2}$ capture. This residual solid blend is then buried in a non-productive area, from which coal was already extracted and is studied in this work. According to the authors experience in development and characterization of adsorbents for low temperature dry desulfurization processes and in Thermogravimetric Analysis, this paper shows and discusses a method which was developed to characterize qualitative and quantitatively the chemical and mineral composition of this waste by using Thermogravimetry coupled with mass spectrometry (TG/MS), X-ray fluorescence (XRF) and X-ray diffraction (XRD), to preview new potential industrial applications for this waste.
\end{abstract}

\section{Key words}

Coal power plant, dry desulfurization, hydrated lime, TG/MS, XRD, and XRF

\section{Acknowledgments}

We are thankful to the University of Cantabria for the financial support under the Project: 51.VP61.64005, to the Brazilian Research Council, under the project CNPq no 407005/2013-7 and to the Brazilian Education Council CAPES.

\footnotetext{
*Corresponding author
} 


\section{Introduction}

Sulphur dioxide is considered an indicator of atmospheric pollution, as it is a major contributor to contamination and environmental degradation, being anthropogenic sources through the combustion of fossil fuels that produce the $80 \%$ of this pollutant [1, 2]. Fossil fuels will still play a key role in the energy mix for the years to come, despite the different prospective frameworks that might be under consideration, and investment in clean fossil fuels technologies is mandatory for taking benefit from this relatively abundant source of energy [3]. In this sense, the reutilization of wastes and by-products and their proper management are important aspects for the sustainability of the processes and are promoted by legislation in some sectors, as is reflected in the Industrial Emissions Directive of the European Union (2010/75/EU).

The techniques for reducing $\mathrm{SO}_{2}$ emissions can be divided in [4, 5]: (i) pre-combustion technologies, that include fuel desulfurization and coal gasification or liquefaction; (ii) during combustion technologies, that includes combustion of coal and limestone mixtures; (iii) post-combustion technologies or flue gas desulfurization (FGD), widely used, in which the flue gas from combustion is put into contact with an alkaline component.

$\mathrm{SO}_{2}$ removal from coal-fired power plant flue gas by desulfurization processes can be done by dry, wet or semi-dry processes [6], using limestone or lime containing products as absorbents or adsorbents.

During the dry desulphurization with commercial hydrated lime the main reaction that occurs is R-1, during which $\mathrm{CaSO}_{3}$ is formed [7], releasing water.

$$
\mathrm{SO}_{2}+\mathrm{Ca}(\mathrm{OH})_{2} \rightarrow \mathrm{CaSO}_{3}+\mathrm{H}_{2} \mathrm{O}
$$

As the used commercial adsorbent contains calcium carbonate, $\mathrm{SO}_{2}$ is also captured by reaction $\mathrm{R}-2$ [7, 8]:

$$
\mathrm{SO}_{2}+\mathrm{CaCO}_{3} \rightarrow \mathrm{CaSO}_{3}+\mathrm{CO}_{2}
$$

The presence of an excess of $\mathrm{Ca}(\mathrm{OH})_{2}$ may adsorb the released $\mathrm{CO}_{2}$, regenerating the calcium carbonate by reaction $\mathrm{R}-3[7,8]$ :

$$
\mathrm{CO}_{2}+\mathrm{Ca}(\mathrm{OH})_{2} \rightarrow \mathrm{Ca} \mathrm{CO}_{3}+\mathrm{H}_{2} \mathrm{O}
$$

Calcium sulphite may be hydrated and partially oxidized, forming the hydrated phases $\mathrm{CaSO}_{3} \cdot 0.5 \mathrm{H}_{2} \mathrm{O}$ and $\mathrm{CaSO}_{4} \cdot 2 \mathrm{H}_{2} \mathrm{0}$, by reactions R-4 and R-5. Double calcium salts as $\mathrm{xCaSO}_{3} \cdot \mathrm{yCaSO}_{4} \cdot \mathrm{nH}_{2} 0$ may be formed as well [9].

$$
\begin{aligned}
& \mathrm{CaSO}_{3}+0.5 \mathrm{H}_{2} \mathrm{O} \rightarrow \mathrm{CaSO}_{3} .0 .5 \mathrm{H}_{2} \mathrm{O} \\
& \mathrm{CaSO}_{3}+0.5 \mathrm{O}_{2}+2 \mathrm{H} \mathrm{O} \rightarrow \mathrm{CaSO}_{4} \cdot 2 \mathrm{H}_{2} 0
\end{aligned}
$$

In a Brazilian coal power plant there is a dry desulfurization unit to capture $\mathrm{SO}_{2}$ with dry solid hydrated lime from the combustion gases. A part of the flying ashes produced in the plant from coal combustion is commercialized and the rest is mixed with the bottom coal ashes and the spent sulphated product generated after $\mathrm{SO}_{2}$ capture. This residual solid blend is then back destined to the coal reserve to be properly buried in a non-productive area, from which coal was already extracted. This is the waste that is studied in this work. 
So in the case that will be shown and discussed in this paper, the compounds that may be present in the final processed hydrated lime (in the waste), depend on the other contaminants present in the commercial hydrated lime, on the particulate solids (fly ashes) carried by the combustion gases trapped by the adsorbing column or present in the bottom ash, as well as on hydrated and carbonated products that may be formed during storage at ambient conditions by humidity and / or carbon dioxide action.

Part of the authors have already developed typical adsorbents to study low temperature dry desulfurization processes [7, 10-12] and have experience in Thermogravimetric Analysis [7, 10, 13-15].

The present paper shows and discusses a method which was developed to characterize qualitative and quantitatively the chemical and mineral composition of this waste by thermogravimetry coupled with mass spectrometry (TG/MS), X-ray fluorescence (XRF) and X-ray diffraction (XRD), to preview new potential industrial applications for this waste.

\section{Materials and Methods}

A sample of the waste was taken in the second semester of 2014, directly from the coal reserve, near to the Brazilian coal power plant. The plant operates in three production units, and only one of them includes a dry desulfurization capture unit. The sample corresponds to a blend of the flying ashes produced in the plant from coal combustion that have not been commercialized, mixed with the bottom coal ashes and the spent sulphated product generated after $\mathrm{SO}_{2}$ capture in the desulfurization unit.

The simultaneous TG-DSC-MS curves were obtained on a SETARAM thermal analyser, model SETSYS1700. The samples of approximately $40 \mathrm{mg}$ were heated in platinum crucibles in Nitrogen atmosphere, at a total flow rate of $100 \mathrm{ml} \mathrm{min}^{-1}$, with a heating rate of $10^{\circ} \mathrm{C} \mathrm{min}^{-1}$ and a final temperature of $1350{ }^{\circ} \mathrm{C}$. All the TG measurements were blank curve corrected. Each experiment was repeated to check for consistency. The TG instrument was coupled to a Balzers Thermostar / OmniStar mass spectrometer (Pfeiffer vacuum) for evolved gas analysis. Quadrupole mass spectrometer model was QMS 200. The number of $\mathrm{m} / \mathrm{z}$ signals selected was: $18.03\left(\mathrm{H}_{2} \mathrm{O}^{+}\right), 32.00\left(\mathrm{O}_{2}{ }^{+}\right), 43.94\left(\mathrm{CO}_{2}{ }^{+}\right), 63.96\left(\mathrm{SO}_{2}{ }^{+}\right), 80\left(\mathrm{SO}_{3}{ }^{+}\right)$. TG-MS analysis supplies in this work only qualitative information.

A representative sample was analysed by X-ray florescence (XRF) using an ARL-ADVANT-XP sequential spectrophotometer to elucidate major and minor elements, using a software UNIQUANT 5.0.

The crystalline components of the sample were identified by X-Ray diffraction using a Bruker Advance 8 diffractometer with a $\mathrm{Cu}$ anode as the $\mathrm{X}$-ray source using $\mathrm{Cu}-\mathrm{K} \alpha$ radiation $(\lambda=1.5418 \AA$ ), connected to a Difrac Plus program. Samples for X-Ray study were prepared by manual milling in a mortar of agate and placed on the sampler. The diffraction figures were compared to the pattern of all the possible crystalline components of the ashes or of the hydrated lime. 


\section{Results and discussion}

Fig. 1 shows the X-ray diffraction pattern obtained, with the main crystalline compounds identified, that include Quartz $\left(\mathrm{SiO}_{2}\right)$, with the most intense peak at $2 \theta=27^{\circ}$, Portlandite $\left(\mathrm{Ca}(\mathrm{OH})_{2}\right)$, with the most intense peaks in order of intensity at $34.10^{\circ}$ and $18.00^{\circ}$, Mullite $\left(\mathrm{Al}_{2} \mathrm{O}_{3} \cdot 0.32 \mathrm{SiO}_{2}\right)$, at $26.27^{\circ}$ and $25.99^{\circ}$, Hydrotalcite $\left(6 \mathrm{MgO} \cdot \mathrm{Al}_{2} \mathrm{O}_{3} \cdot \mathrm{CO}_{2} \cdot 12 \mathrm{H}_{2} \mathrm{O}\right)$, Brucite $\left(\mathrm{Mg}(\mathrm{OH})_{2}\right)$, at $37.98^{\circ}$ and $18.58^{\circ}$, Gypsum $\left(\mathrm{CaSO}_{4} \cdot 2 \mathrm{H}_{2} \mathrm{O}\right)$, at $31.13^{\circ}$ and $20.74^{\circ}$, Ettringite $\left(6 \mathrm{CaO} \cdot \mathrm{Al}_{2} \mathrm{O}_{3} \cdot 3 \mathrm{SO}_{3} \cdot 32 \mathrm{H}_{2} \mathrm{O}\right)$, at $9.09^{\circ}$ and $15.78^{\circ}$, Calcite $\left(\mathrm{CaCO}_{3}\right)$, at $29.36^{\circ}$ and $47.31^{\circ}$, Magnesite $\left(\mathrm{MgCO}_{3}\right)$, at $33.15^{\circ}$ and $43.04^{\circ}$, and calcium sulphite hemihydrate $\left(\mathrm{CaSO}_{3} \cdot 0.5 \mathrm{H}_{2} \mathrm{O}\right)$ at $29.05^{\circ}$ and $35.33^{\circ}$. It can be also observed the characteristic pattern that is ascribed to amorphous compounds of fly ash at $2 \theta=15-40^{\circ}, 2 \theta=40-45^{\circ}$ and $2 \theta=45-53^{\circ}$.

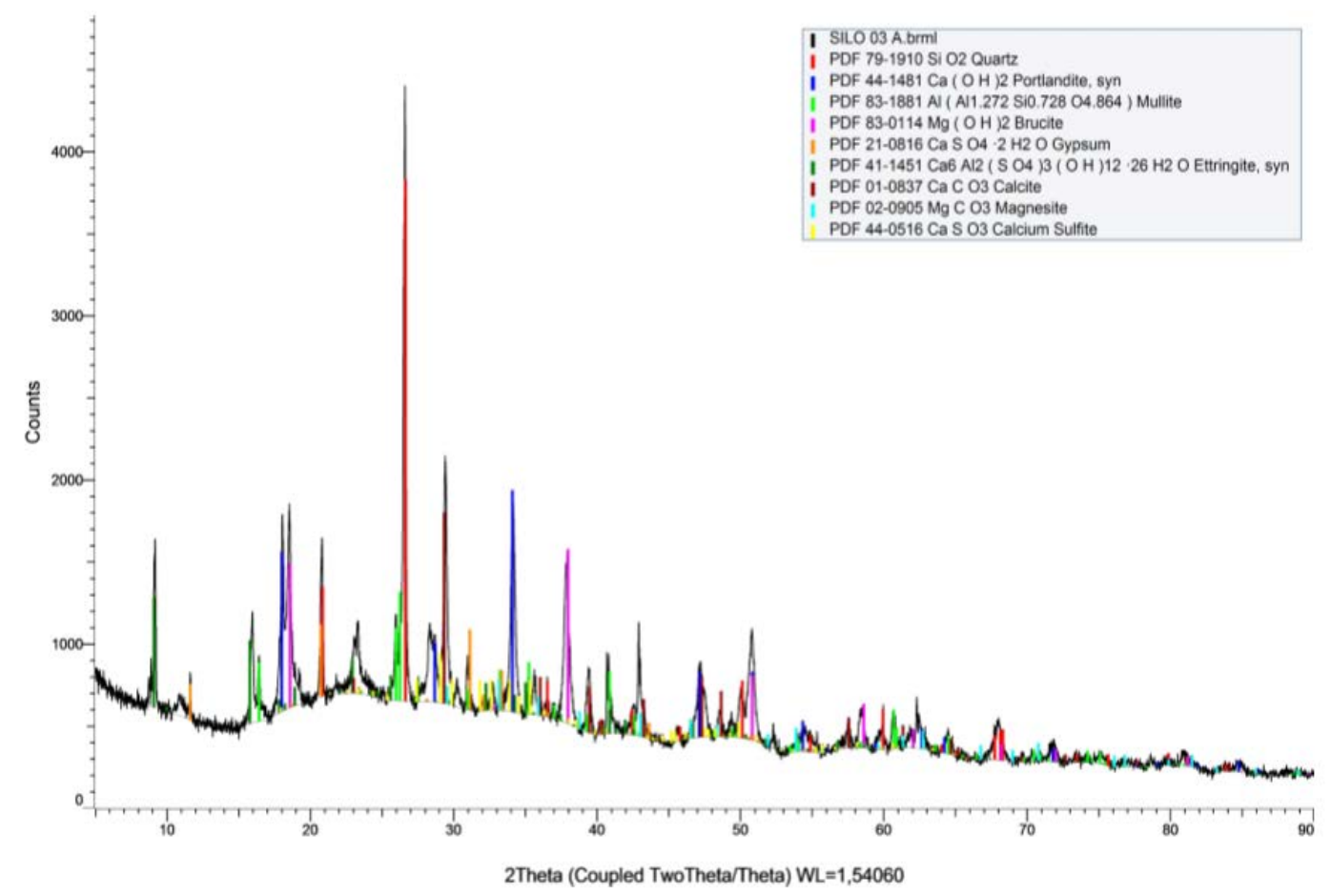

Fig. 1 X-ray diffraction pattern for the coal power plant waste.

As it has been introduced, Portlandite $\left(\mathrm{Ca}(\mathrm{OH})_{2}\right)$, Calcite $\left(\mathrm{CaCO}_{3}\right)$, Calcium Sulphite Hemihydrate and Gypsum come from the non-reacted hydrated lime, ambient hydration and carbonation action during storage and the desulphurization products, being present also Brucite $\left(\mathrm{Mg}(\mathrm{OH})_{2}\right)$, Magnesite $\left(\mathrm{MgCO}_{3}\right)$ and Hydrotalcite $\left(6 \mathrm{MgO} \cdot \mathrm{Al}_{2} \mathrm{O}_{3} \cdot \mathrm{CO}_{2} \cdot 12 \mathrm{H}_{2} \mathrm{O}\right)$ in the commercial hydrated lime used. The rest of the crystalline compounds come from the fly ash.

Fig. 2 shows TG-DTG results obtained in 100\% nitrogen atmosphere. 


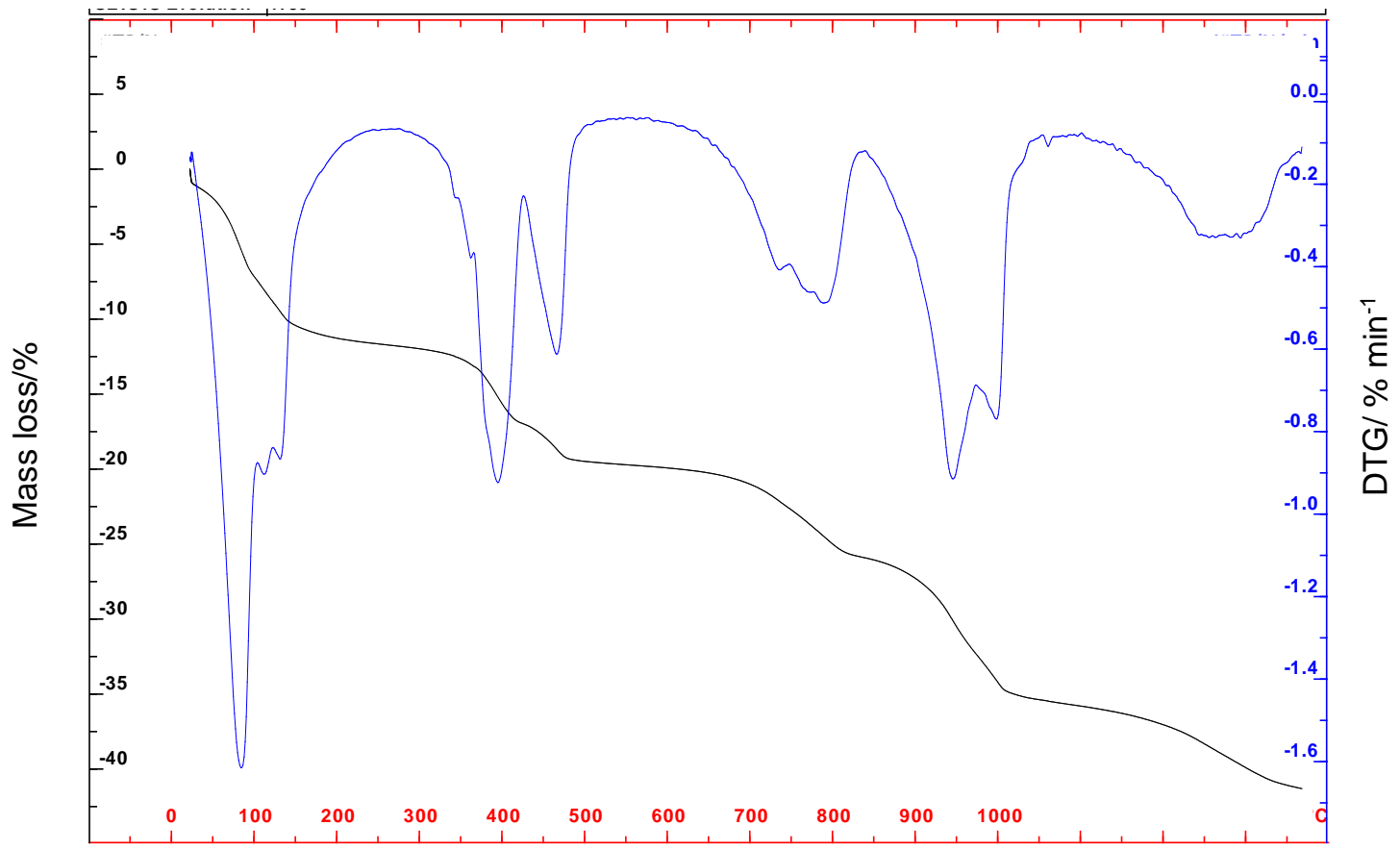

Temperature $/{ }^{\circ} \mathrm{C}$

Fig. 2 TG and DTG of the coal power plant waste, using $\mathrm{N}_{2}$ as the carrier gas, $10^{\circ} \mathrm{C} / \mathrm{min}$ and $100 \mathrm{ml} / \mathrm{min}$.

As it can be observed by DTG results, many stages are involved in each mass loss step observed in the TG curve. Because of that, the losses will be assigned in the next section "TG-MS results".

To help the interpretation of the complex thermal analysis curves that were obtained with many decomposing steps, a review of thermal decomposition properties of the products that were identified by $\mathrm{X}$ ray diffraction (XRD) was done, which main reactions are presented in the following items.

\section{Calcium sulphite thermal decomposition}

$\mathrm{CaSO}_{3} \cdot 0.5 \mathrm{H}_{2} \mathrm{O}$ is obtained in humid ambient and exists in three crystallographic structures, but concerning with the $\alpha$ (orthorhombic) form, the dehydration process are referred to take place at about $297-400^{\circ} \mathrm{C}$ [16] or between 360 and $410^{\circ} \mathrm{C}[17]$.

$$
\mathrm{CaSO}_{3} \cdot 0.5 \mathrm{H}_{2} \mathrm{O} \rightarrow \mathrm{CaSO}_{3}+0.5 \mathrm{H}_{2} \mathrm{O}
$$

Renedo et al [7], in their study of $\mathrm{CO}_{2}$ and $\mathrm{SO}_{2}$ sorption by calcium hydroxide using simultaneous thermogravimetry, differential scanning calorimetry and mass spectrometry (TG/DSC/MS), have shown that the dehydration of $\mathrm{CaSO}_{3} .0 .5 \mathrm{H}_{2} \mathrm{O}$ occurs at $275-375^{\circ} \mathrm{C}$ temperature range.

Ciurowa [18] studied the thermal decomposition of $\mathrm{CaSO}_{3}$ in air and nitrogen ambient by TG, differential thermal analysis (DTA) and XRD. In air, $\mathrm{CaSO}_{3}$ may be partially oxidized from $450^{\circ} \mathrm{C}$ to $\mathrm{CaSO}_{4}$, as shown in 
reaction R-7 but it also may suffer a disproportion reaction (R-8) from $600^{\circ} \mathrm{C}$, which also occurs in $\mathrm{N}_{2}$ atmosphere, forming $\mathrm{CaSO}_{4}$ and $\mathrm{CaS}$, which is completed at $850^{\circ} \mathrm{C}$ :

$$
\begin{aligned}
& \mathrm{CaSO}_{3}+0.5 \mathrm{O}_{2} \rightarrow \mathrm{CaSO}_{4} \\
& 4 \mathrm{CaSO}_{3} \rightarrow 3 \mathrm{CaSO}_{4}+\mathrm{CaS}
\end{aligned}
$$

In nitrogen, above $900^{\circ} \mathrm{C}$, calcium sulphate and calcium sulphide react with each other forming calcium oxide and sulphurous oxide as per reaction R-9, also reported by Zhao et al [19] in a temperature range of 849$1119^{\circ} \mathrm{C}$ :

$$
3 \mathrm{CaSO}_{4}+\mathrm{CaS} \rightarrow 4 \mathrm{CaO}+4 \mathrm{SO}_{2}
$$

In oxidant atmosphere, $\mathrm{CaS}$ is oxidized to $\mathrm{CaSO}_{3}$ from $450^{\circ} \mathrm{C}$ and at higher temperatures, to $\mathrm{CaSO}_{4}$ [18]. This oxidation steps were also reported by Dweck [20], when analyzing a solid residue containing calcium sulphide heated in air.

\section{Calcium sulphate thermal decomposition}

Thermal decomposition of Gypsum $\mathrm{CaSO}_{4} \cdot 2 \mathrm{H}_{2} \mathrm{O}$ occurs in two steps: in the first, Plaster of Paris $\left(\mathrm{CaSO}_{4} \cdot 0.5 \mathrm{H}_{2} \mathrm{O}\right)$ is obtained by reaction $\mathrm{R}-10$, and in the second one, $\gamma$-anhydrous calcium sulfate $\left(\gamma \mathrm{CaSO}_{4}\right)$ is produced by reaction $\mathrm{R}-11$ [21-24]:

$$
\begin{aligned}
& \mathrm{CaSO}_{4} \cdot 2 \mathrm{H}_{2} \mathrm{O} \rightarrow \mathrm{CaSO}_{4} \cdot 0.5 \mathrm{H}_{2} \mathrm{O}+1.5 \mathrm{H}_{2} \mathrm{O} \\
& \mathrm{CaSO}_{4} \cdot 1 / 2 \mathrm{H}_{2} \mathrm{O} \rightarrow \mathrm{CaSO}_{4}+0.5 \mathrm{H}_{2} \mathrm{O}
\end{aligned}
$$

At elevated heating rates R-10 and R-11 may occur simultaneously, which are equivalent to reaction R-12 [22, 25]:

$$
\mathrm{CaSO}_{4} \cdot 2 \mathrm{H}_{2} \mathrm{O} \rightarrow \mathrm{CaSO}_{4}+2 \mathrm{H}_{2} \mathrm{O}
$$

According to this, dehydration of gypsum may take place within the $75-130^{\circ} \mathrm{C}$ range [21], or apparently with a continuous water loss in the $63-106^{\circ} \mathrm{C}$ range [22], between $150-250^{\circ} \mathrm{C}$ [26] or at $156^{\circ} \mathrm{C}$ and $184^{\circ} \mathrm{C}$ [24].

Reaction R-10 may begin at $34^{\circ} \mathrm{C}$ in dry air [27] and at higher temperatures when the water ambient vapor partial pressure $\left(\mathrm{p}_{\mathrm{w}}\right)$ increases. Actually reactions R-10 to R-12 are reversible, but if anhydrous $\gamma$ calcium sulphate is heated above $400^{\circ} \mathrm{C}$, rehydration is practically impossible, because a crystalline phase change occurs transforming it to $\beta \mathrm{CaSO}_{4}$, which practically cannot be rehydrated [28].

Thermal decomposition of $\mathrm{CaSO}_{4}$ in air occurs only at high temperatures $\left(1200-1250^{\circ} \mathrm{C}\right)$ by reaction R-13 [29]:

$$
\mathrm{CaSO}_{4} \rightarrow \mathrm{CaO}+\mathrm{SO}_{2}+1 / 2 \mathrm{O}_{2}
$$

In inert or reducing atmosphere, thermal decomposition of metal sulfates occurs at lower temperatures than in oxidant atmosphere [30,31]. 
Thermal decomposition of other compounds present in the waste

The temperatures of dehydration of Portlandite (about $400-575^{\circ} \mathrm{C}$ ) and brucite (about $350-400^{\circ} \mathrm{C}$ ) and of the decomposition of calcite (DTG peak at $936^{\circ} \mathrm{C}$, but can be lower depending on the well crystallized variation) and Magnesite $\left(620-650^{\circ} \mathrm{C}\right)$ are widely found in literature and previous works [24, 26, 32, 33].

Hydrotalcites, also known as layered double hydroxides (LDH's) or ionic clays, are natural minerals (but also synthetic) based upon the brucite $\left[\mathrm{Mg}(\mathrm{OH})_{2}\right]$ structure in which some of the divalent cations are replaced by trivalent cations (e.g. $\mathrm{Al}$ or $\mathrm{Fe}$ ) resulting in a layer charge. This layer charge is counterbalanced by anions such as carbonate or sulfate in the interlayer. For the carbonate intercalated hydrotalcite, dehydration takes place in three steps, between 29 and $235^{\circ} \mathrm{C}$ [34] or up to $259^{\circ} \mathrm{C}$ [35].

Alonso and Fernández [36] described by TG/DTA/DSC the endothermic peak at about $100^{\circ} \mathrm{C}$ in that the ettringite disappears after heating and recovers after rehydration, also described in other works by Shimada and Young [37].

It must be noted that during thermal analyses, dry purge gases may accelerate dehydration reactions to much lower temperatures than those mentioned above, because they act decreasing significantly the vapour partial pressure above the decomposing sample. The same effect occurs with purge gases that do not have $\mathrm{CO}_{2}$ in their composition, with respect to decarbonation reactions, because carrying away any $\mathrm{CO}_{2}$ right after it is formed, they act on the equilibrium of those reactions enhancing a higher formation of $\mathrm{CO}_{2}$, decreasing significantly the temperature range of the decarbonation reactions [14].

TG-MS results

Fig. 3 shows the TG-MS obtained results, within the interval of temperature in which the peaks of $\mathrm{H}_{2} 0$ (18.03), $\mathrm{O}_{2}$ (32.00), $\mathrm{CO}_{2}(43.94)$ and $\mathrm{SO}_{2}(63.96)$ appear. The $\mathrm{m} / \mathrm{z}$ signal $80\left(\mathrm{SO}_{3}{ }^{+}\right)$does not appear because at temperatures higher than $700^{\circ} \mathrm{C}, \mathrm{SO}_{3}$ is unstable, decomposing to $\mathrm{SO}_{2}$ and $1 / 2 \mathrm{O}_{2}$ and as shown in $\mathrm{R}-13$ and as seen in Figure 3 due to the decomposition of some sulphate.

It can be observed that the loss of water takes place in a first complex interval until $250^{\circ} \mathrm{C}$, and in a second complex interval from this temperature up to $450^{\circ} \mathrm{C}$, being the loss of $\mathrm{CO}_{2}$ found between 600 and $800^{\circ} \mathrm{C}$ approximately.

As will be shown in Figure 3, all the water and carbon dioxide released from the thermal decomposition of the components present in the sample are eliminated before $900^{\circ} \mathrm{C}$, and sulphite or sulphate products are decomposed above that temperature. According to these results, the losses of $\mathrm{CO}_{2}$ and $\mathrm{SO}_{2}$ are not overlapped. 


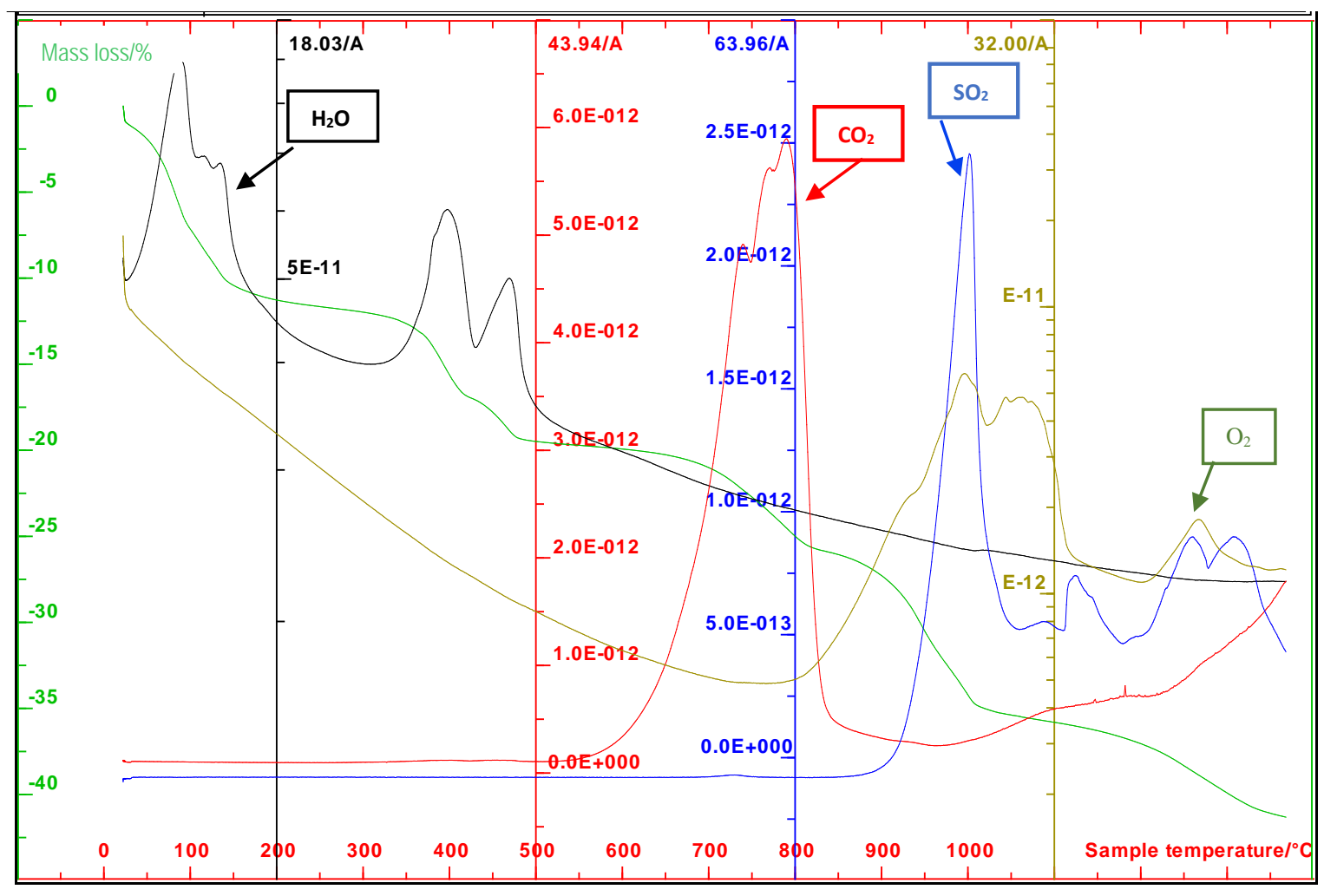

Temperature $/{ }^{\circ} \mathrm{C}$

Fig. 3 TG-MS results of the coal power plant waste in nitrogen atmosphere, $10^{\circ} \mathrm{C} / \mathrm{min}, 100 \mathrm{ml} / \mathrm{min}$, showing the MS curves of $\mathrm{H}_{2} \mathrm{O}$ (18.03), $\mathrm{O}_{2}$ (32.00), $\mathrm{CO}_{2}$ (43.94) and $\mathrm{SO}_{2}$ (63.96) in arbitrary units (A)

The mass loss steps (TG signal, left-y axis) in Fig. 2, according also to Fig. 3, can be ascribed as water loss $\left(<320^{\circ} \mathrm{C}\right)$, that includes at least the free water and also, according to the revision carried out, combined water from hydrotalcite, ettringite and gypsum; the second complex dehydration process may comprise the dehydration of sulphite hemihydrate, $\mathrm{Mg}(\mathrm{OH})_{2}$ dehydration $\left(320-420^{\circ} \mathrm{C}\right)$ and $\mathrm{Ca}(\mathrm{OH})_{2}$ dehydration (420$520^{\circ} \mathrm{C}$ ). A complex $\mathrm{CO}_{2}$ release that includes that from $\mathrm{MgCO}_{3}$ decomposition (550-750 ${ }^{\circ} \mathrm{C}$ ), hydrotalcite decarbonation $\left(750-800^{\circ} \mathrm{C}\right)$ and $\mathrm{CaCO}_{3}$ decarbonation $\left(800-870{ }^{\circ} \mathrm{C}\right)$. Along with the mass loss steps, the MS signal in figure 3 (63.96/A) shows a $\mathrm{SO}_{2}$ release from $870{ }^{\circ} \mathrm{C}$, which can be attributed to the decomposition of calcium sulphite according to R-8 and R-9 or R-14 [7] and to calcium sulphate decomposition according to R13 and also to reactions R-15 and R-16, as discussed below.

$$
\mathrm{CaSO}_{3} \rightarrow \mathrm{CaO}+\mathrm{SO}_{2}
$$

Marchal, in her study of $\mathrm{CaSO}_{4}$ decomposition at elevated temperatures [38] and more recently Mihara et al [39] and Yan et al [40] reported that the presence of $\mathrm{Fe}_{2} \mathrm{O}_{3}$ or $\mathrm{SiO}_{2}$ promotes $\mathrm{CaSO}_{4}$ decomposition from about $900^{\circ} \mathrm{C}$, by reactions similar to R-15 and R-16, respectively:

$$
\mathrm{CaSO}_{4}+\mathrm{Fe}_{2} \mathrm{O}_{3} \rightarrow \mathrm{CaO} . \mathrm{Fe}_{2} \mathrm{O}_{3}+\mathrm{SO}_{2}+1 / 2 \mathrm{O}_{2}
$$




$$
2 \mathrm{CaSO}_{4}+\mathrm{SiO} 2 \rightarrow \mathrm{SiO}_{2} \cdot 2 \mathrm{CaO}+2 \mathrm{SO}_{2}+\mathrm{O}_{2}
$$

These reactions may explain the many oxygen release peaks identified in the TG-MS curves of the waste in $\mathrm{N}_{2}$ atmosphere in Figure 3, occurring simultaneously to the many $\mathrm{SO}_{2}$ released peaks.

Mineral and chemical composition of the waste

The X-ray Fluorescence results obtained are showed in Table 1 as oxides in percentage. The results found considering the loss on ignition (LOI) value calculated from TG data until $900^{\circ} \mathrm{C}$ in $\mathrm{N}_{2}$ atmosphere are also shown, which correspond to the sum of the losses of water and $\mathrm{CO}_{2}$.

Table 1 Composition of the waste according to XRF analysis and corrected XRF values considering the loss on ignition (LOI) determined by TG of the sample in $\mathrm{N}_{2}$ up to $900^{\circ} \mathrm{C}$

\begin{tabular}{|c|c|c|}
\hline Composition & XRF analysis / \% & Corrected XRF with LOI from TG / \% \\
\hline $\mathrm{MgO}$ & 10.378 & 7.570 \\
\hline $\mathrm{Al}_{2} \mathrm{O}_{3}$ & 6.496 & 4.738 \\
\hline $\mathrm{SiO}_{2}$ & 15.740 & 11.481 \\
\hline $\mathrm{SO}_{3}$ & 17.913 & 13.066 \\
\hline $\mathrm{K}_{2} \mathrm{O}$ & 0.700 & 0.511 \\
\hline $\mathrm{CaO}$ & 45.759 & 33.378 \\
\hline $\mathrm{TiO}_{2}$ & 0.311 & 0.227 \\
\hline $\mathrm{Fe}_{2} \mathrm{O}_{3}$ & 2.252 & 1.643 \\
\hline $\mathrm{ScO}_{3}$ & 0.349 & 0.255 \\
\hline $\mathrm{SrO}$ & 0.092 & 0.067 \\
\hline $\mathrm{Rb}_{2} \mathrm{O}$ & 0.009 & 0.007 \\
\hline Free water & & 1.018 \\
\hline 1 st comb $\mathrm{H}_{2} \mathrm{O}$ set & & 10.721 \\
\hline 2nd comb $\mathrm{H}_{2} \mathrm{O}$ set & & 7.703 \\
\hline Total water content & & 19.438 \\
\hline $\mathrm{CO}_{2}$ & & 7.618 \\
\hline LOI & & 27.056 \\
\hline
\end{tabular}


An excel program was designed to estimate the quantitative mineral composition of the waste, being the obtained results shown in Table 2. This table shows in the first two horizontal files the composition obtained from corrected XRF results in Table 1, obtained from XRF and TG-MS results. The first column in Table 2 shows the compounds identified by XRD and other oxides assigned according to corrected XRF results. This column represents the qualitative mineral composition of the studied waste.

Each column presents the distribution of each oxide in the different compounds identified by XRD (or in the form of oxides if their presence was not confirmed in XRD). The columns LOI $\mathrm{H}_{2} \mathrm{O}$ and $\mathrm{LOI} \mathrm{CO}_{2}$ represent the percentage of water or $\mathrm{CO}_{2}$ in each crystalline compound identified in XRD.

The dashed line cells values in Table 2 were obtained from respective TG curve mass loss graphically (from the partial mass loss of each DTG peak limit of each higher mass loss step), considering bibliographic data of the mass loss temperature interval; the other values were obtained stoichiometrically or by mass balance of each oxide, using the excel program for calculation. The excel program allows doing hypothesis analysis, being quickly the calculation when a change in one cell is proposed, and allowing the assignation of the different values obtained in the TG for combined water from hydrotalcite, ettringite and gypsum.

The second column in Table 2, obtained as the sum of each file, represents the quantitative estimated composition of the coal power plant waste. As can be seen at the end of the second column, practically $99 \%$ of the composition was estimated by using this methodology.

Table 2 Qualitative and quantitative composition of the coal power plant waste according to corrected XRF composition, compounds identified by XRD, TG-DTG losses data, stoichiometry and mass balance

\begin{tabular}{|c|c|c|c|c|c|c|c|c|c|c|c|c|c|c|}
\hline Component / Oxide & $\mathrm{m}(\%)$ & $\begin{array}{l}\mathrm{LOI} \\
\mathrm{H}_{2} \mathrm{O}\end{array}$ & $\begin{array}{l}\mathrm{LOI} \\
\mathrm{CO}_{2} \\
\end{array}$ & $\mathrm{MgO}$ & $\mathrm{Al}_{2} \mathrm{O}_{3}$ & $\mathrm{SiO}_{2}$ & $\mathrm{SO}_{3}$ & $\mathrm{~K}_{2} \mathrm{O}$ & $\mathrm{CaO}$ & $\mathrm{TiO}_{2}$ & $\mathrm{Fe}_{2} \mathrm{O}_{3}$ & $\mathrm{Sc}_{2} \mathrm{O}_{3}$ & $\mathrm{SrO}$ & $\mathrm{Rb}_{2} \mathrm{O}$ \\
\hline free $\mathrm{H}_{2} \mathrm{O}$ & 1.02 & 1.02 & & & & & & & & & & & & \\
\hline $\mathrm{SiO}_{2}$ quartz & 11.18 & & & & & 11.18 & & & & & & & & \\
\hline $\mathrm{Al}_{2} \mathrm{O}_{3} \cdot 0.32 \mathrm{SiO}_{2}$ & 1.90 & & & & 1.60 & 0.30 & & & & & & & & \\
\hline $6 \mathrm{CaO} \cdot \mathrm{Al}_{2} \mathrm{O}_{3} \cdot 3 \mathrm{SO}_{3} \cdot 32 \mathrm{H}_{2} \mathrm{O}$ & 2.69 & 1.24 & & & 0.22 & & 0.51 & & 0.72 & & & & & \\
\hline $6 \mathrm{MgO} \cdot \mathrm{Al}_{2} \mathrm{O}_{3} \mathrm{CO}_{2} \cdot 12 \cdot \mathrm{H}_{2} \mathrm{O}$ & 14.47 & 6.18 & 1.26 & 4.12 & 2.92 & & & & & & & & & \\
\hline $\mathrm{CaSO}_{4} \cdot 2 \mathrm{H}_{2} \mathrm{O}$ & 15.81 & 3.31 & & & & & 7.35 & & 5.15 & & & & & \\
\hline $\mathrm{CaSO}_{3} \cdot 0.5 \mathrm{H}_{2} \mathrm{O}$ & 8.38 & 0.58 & & & & & 5.20 & & 3.64 & & & & & \\
\hline $\mathrm{Mg}(\mathrm{OH})_{2}$ & 1.68 & 0.41 & & 1.28 & & & & & & & & & & \\
\hline $\mathrm{Ca}(\mathrm{OH})_{2}$ & 27.56 & 6.70 & & & & & & & 20.86 & & & & & \\
\hline $\mathrm{MgCO}_{3}$ & 6.17 & & 3.99 & 2.18 & & & & & & & & & & \\
\hline $\mathrm{CaCO}_{3}$ & 5.38 & & 2.37 & & & & & & 3.01 & & & & & \\
\hline $\mathrm{TiO}_{2}$ & 0.23 & & & & & & & & & 0.23 & & & & \\
\hline $\mathrm{Fe}_{2} \mathrm{O}_{3}$ & 1.64 & & & & & & & & & & 1.64 & & & \\
\hline $\mathrm{Sc}_{2} \mathrm{O}_{3}$ & 0.25 & & & & & & & & & & & 0.25 & & \\
\hline $\mathrm{SrO}$ & 0.07 & & & & & & & & & & & & 0.07 & \\
\hline $\mathrm{K}_{2} \mathrm{O}$ & 0.51 & & & & & & & 0.51 & & & & & & \\
\hline $\mathrm{Rb}_{2} \mathrm{O}$ & 0.01 & & & & & & & & & & & & & 0.01 \\
\hline Total & 98.95 & 19.44 & 7.62 & 7.57 & 4.74 & 11.48 & 13.07 & 0.51 & 33.38 & 0.23 & 1.64 & 0.25 & 0.07 & 0.01 \\
\hline
\end{tabular}


According to XRF, XRD, TG-MS, and results from Table 2, the composition estimated for this waste presents a high ratio of dry spent desulfurization sorbent, being $\mathrm{Ca}(\mathrm{OH})_{2}$ the major component of the waste (27.56\%), that corresponds to the non-reacted hydrated lime (or $\mathrm{CaO}$ from fly ash hydrated, according to the atmospheric deposits), followed by gypsum as the main present product (15.81\%) and hemihydrated calcium sulphite in lesser extent (8.38\%). Very probably the higher gypsum content can be a consequence of the oxidation and hydration of the hemihydrated calcium sulphite formed in the $\mathrm{SO}_{2}$ absorbing unit, during storage. It is also important the presence of hydrotalcite (14.47\%) and quartz (11.18\%), the first one from the commercial hydrated lime used in the adsorption tower, and the second from the fly ash, as in the case of the mullite $(1.90 \%)$, being ettringite $(2.69 \%)$ a product of desulphurization when fly ash is present. Calcite (5.38\%) and Magnesite (6.17\%) are also in important amounts from dolomite accompanying the commercial hydrated lime.

Taking into account the valorisation options found in the bibliography for dry FGD products [39, 41-43] and these results, the high percentage of hydrated lime and other basic compounds like magnesite or calcite can make advisable to explore the reuse of this waste in the same dry FGD unit, alone or after reactivation, its use in the $\mathrm{CO}_{2}$ capture, or its use as a soil amendment for alkalized soil, added to the most common use in concrete admixture.

\section{Conclusions}

A method has been developed to characterize qualitative and quantitatively the chemical and mineral composition of a coal power plant waste with data obtained from thermogravimetry coupled with mass spectrometry (TG/MS), X-ray fluorescence (XRF) and X-ray diffraction (XRD) that allowed estimating its composition. The high percentage of hydrated lime and other basic compounds like magnesite or calcite, can make advisable the reuse of this waste in the same FGD unit, its use in the $\mathrm{CO}_{2}$ capture, or as a soil amendment for alkalized soil, added to the most common use in concrete admixture.

\section{References}

1. Davini P. Behaviour of certain by-products from the manufacture of marble in the desulphation of flue gases. Resour Conserv Recycl. 1992;6:139-48.

2. Hlincik T, Buryan P. Evaluation of limestones for the purposes of desulphurisation during the fluid combustion of brown coal. Fuel. 2013;104:208-15.

3. IEA-International Energy Agency. Word Energy Investment Outlook 2014. In: Word Energy Outlook 2014.http://www.iea.org/publications. Accessed 20 Jul 2015.

4. Lee CC, Huffman GL. Wet and Dry Scrubbers for Emission Control. In: Lee CC and Dar Lin S, editors. Handbook of Environmental Engineering Calculations. New York: McGraw-Hill; 2007. pp. 3103-3140.

5. Valle-Zermeño R, Formosa J, Chimenos JM. Wet Flue Gas Desulfurization using alkaline agents: A Review. Reviews in Chemical Engineering. 2015;31:303-27. 
6. A Review of literature related to the use of spray dryer absorber material: production characterization, utilization applications, barriers, and recommendations. EPRI, Palo Alto, CA and UND EERC CARRC, Grand Forks, ND: 2007. 1014915.

7. Renedo MJ, Pesquera C, González F, Fernández J. Use of TG-DSC-MS and Gas analyzer data to investigate the reaction of $\mathrm{CO}_{2}$ and $\mathrm{SO}_{2}$ with $\mathrm{Ca}(\mathrm{OH})_{2}$ at low temperature. Chem Eng Trans. 2013;35:739-44.

8. National Lime Association, Wet flue gas desulfurization technology evaluation, Project Number 11311-000, 2003 Downloaded in 1/7/2015 from: http://www.graymont.com/sites/default/files/pdf/tech_paper/wet_flue_gas_desulfurization_technology_evalua tion 0 1.pdf

9. Buecker B, Blaine R. Thermogravimetry: A great tool for flue gas desulfurization solids analysis. TA Instruments Application Note TA-318, USA.

10. Fernández J, Rico JL, García H, Renedo MJ. Development of Sorbents for $\mathrm{SO}_{2}$ Capture Prepared by Hydration of Fly Ash and Hydrated Lime in Seawater. Ind Eng Chem Res. 2006;45:856-62.

11. Renedo MJ, González F, Pesquera C, Fernández J. Study of sorbents prepared from clays and $\mathrm{CaO}$ or $\mathrm{Ca}(\mathrm{OH})_{2}$ for $\mathrm{SO}_{2}$ removal at low temperature. Ind Eng Chem Res. 2006;45:3752-57.

12. Renedo MJ, González PL, Fernández J. X-ray diffraction analysis of desulfurant sorbents prepared by mixing calcined sewage sludge and $\mathrm{CaO}$ in distilled or sea water. Chem Eng Trans. 2012;29:1045-50.

13. Neves JrA, Santos Lemos M, Toledo Filho RD, Fairbaim EMR, Dweck J. Early stages hydration of high initial strength Portland cement, Part II. NCDTA and Vicat Analysis J Therm Anal Calorim. 2013;113: $659 \neg 65$.

14. Dweck J, Melchert MBM, Viana MM, Cartledge FK, Büchler PM. Importance of quantitative thermogravimetry on initial cement mass basis to evaluate the hydration of cement pastes and mortars. $\mathrm{J}$ Therm Anal Calorim. 2013;111 (3):1-10.

15. Neves Junior A, Toledo Filho RD, Fairbairn EMR, Dweck $\mathrm{J} \mathrm{CO}_{2}$ sequestration by high initial strength Portland cement pastes. J Therm Anal Calorim. 2013;113:1577-84.

16. Anderson C, Galwey AK. A kinetic study of the thermal dehydration of calcium sulphite hemihydrate. Can J Chem. 1992;70:2468-75.

17. Guan B, Fu H, Yu J, Jiang G, Kong B, Wu Z. Direct transformation of calcium sulphite to a-calcium sulphate hemihydrate in a concentrated $\mathrm{Ca}-\mathrm{Mg}-\mathrm{Mn}$ chloride solution under atmospheric pressure. Fuel. 2011;90:3641.

18. Ciurowa KW. The thermal behaviour of compounds in the Ca-S-O system, J Therm Anal. 1992;38:523-30.

19. Zhao L, Wan T, Yang X, Yang L, Kong X, Zhang Z, Wang X. Effects of kaolinite addition on the melting characteristics of the reaction between phosphogypsum and CaS. J Therm Anal Calorim. 2015;119:2119ᄀ26.

20. Dweck J. Laboratory scale sulphur recovery from a sulphuric acid production solid waste. Dr. Eng Thesis, São Paulo University, Chem Eng Department, 1990. (In Portuguese)

21. Ballirano P, Melis E. Thermal behaviour and kinetics of dehydration of gypsum in air from in situ real-time laboratory parallel-beam X-ray powder diffraction. Phys Chem Minerals. 2009;36:391-402.

22. Putnis A, Winkler B, Diaz LF. In situ IR spectroscopic and thermogravimetric study of the dehydration of gypsum. Mineral Mag. 1990;54:123-28.

23. Dweck J, Lasota EIP. Quality Control of Commercial Plasters by Thermogravimetry. Thermochim Acta. 1998;318:137-42.

24. Tydlitát V, Trník A, Scheinherrová L, Podoba R. Application of isothermal calorimetry and thermal analysis for the investigation of calcined gypsum-lime-metakaolin-water system. J Therm Anal Calorim. 2015;122:115 22 .

25. Dweck J, Souza Santos P. Prototype System for Thermogravimetric Analyses. Cerâmica. 1989; 35 (239): 16975.

26. Földvári M. Handbook of thermogravimetric system of minerals and its use in geological practice. Geological Institute of Hungary, Budapest, 2011.

27. Norton FH. Fine Ceramics. McGraw Hill, New York, 1970: 110.

28. Dweck J, Andrade BF, Monteiro EEC, Fischer R. Thermal Characterization of Polymeric Plaster Composites. J Therm Anal Cal. 2002;67:321-6.

29. Swift WM, Panek AF, Smith GW, Vogel JG, Jonke AA. Decomposition of calcium sulphate: a review of the literature. Argonne National Laboratory Report, Argonne, Illinois, 1976.

30. Miao Z, Yang H, Wu Y, Zhang H, Zhang X. Experimental Studies on Decomposing Properties of Desulfurization Gypsum in a Thermogravimetric Analyzer and Multiatmosphere Fluidized Beds. Ind Eng Chem Res. 2012;51:5419-23. 
31. Hammerschmidt J, Wrobel M. Decomposition of metal sulphates - a $\mathrm{SO}_{2}$ source for sulphuric acid production, The Southern African Institute of Mining and Metallurgy Sulphur and Sulphuric Acid Conference Proceed. 2009;1:87.

32. Garea A, Fernández I, Viguri JR, Ortiz MI, Fernández J, Renedo MJ, Irabien JA. Thermogravimetric Determination of the Influence of Water Vapour in the FGD In-Duct Injection at Low Temperatures. J Chem Technol Biotechnol. 2000;75:1-7.

33. Valle-Zermeño R, Montiano-Redondo J, Formosa J, Chimenos, JM, Renedo MJ, Fernández, J. Reutilization of $\mathrm{MgO}$ by-products from the calcination of natural magnesite in dry desulfurization: A closed-loop process. Energy \& Fuels. 2015;29:3845-54.

34. Vágvölgyi V, Palmer SJ, Kristóf J, Frost RL, Horváth E. Mechanism for hydrotalcite decomposition: A controlled rate thermal analysis study. Journal of Colloid and Interface Science. 2008;318:302-08.

35. Zhang J, Feng Xu Y, Qian G, Ping Xu Z, Chen C, Liu Q. Reinvestigation of Dehydration and Dehydroxylation of Hydrotalcite-like Compounds through Combined TG-DTA-MS Analyses. J Phys Chem C. 2010;114:10768-74.

36. Alonso C, Fernández L. Dehydration and rehydration processes of cement paste exposed to high temperature environments. J. Mater. Sci. 2004;39:3015 -24.

37. Shimada Y, Young JF. Structural changes during thermal dehydration of ettringite. Adv Cem Res. 2001;13: 77-81.

38. Marchal G. Recherches sur la Decomposition des Sulfates Metalliques par la Chaleur. J Chem Phis. 1926;23: 38-60.

39. Mihara N, Kuchar D, Kojima Y, Matsuda H. Reductive decomposition of waste gypsum with $\mathrm{SiO}_{2}, \mathrm{Al}_{2} \mathrm{O}_{3}$, and $\mathrm{Fe}_{2} \mathrm{O}_{3}$ additives. J Mater Cycles Waste Manag. 2007;9:21-6.

40. Yan Z, Wang Z, Liu H, Tu Y, Yang W, Zeng H, Qiu J. Decomposition and solid reactions of calcium sulfate doped with $\mathrm{SiO}_{2}, \mathrm{Fe}_{2} \mathrm{O}_{3}$ and $\mathrm{Al}_{2} \mathrm{O}_{3}$. Journal of Analytical and Applied Pyrolysis 2015;113:491-8.

41. Li Y, Zheng K, You C. Experimental study on the reuse of spent rapidly hydrated sorbent for circulating fluidized bed flue gas desulfurization. Environ Sci Technol. 2011;45(21):9421-6.

42. Matsushima N, Li Y, Nishioka M, Sadakata M, Qi H, Xu X. Novel Dry-Desulfurization Process Using $\mathrm{Ca}(\mathrm{OH}) 2 /$ Fly Ash Sorbent in a Circulating Fluidized Bed. Environ. Sci. Technol. 2004;38:6867-74.

43. Lee MG, Ryu KW, Chae SC, Jang YN. Effects of temperature on the carbonation of flue gas desulphurization gypsum using a $\mathrm{CO}_{2} / \mathrm{N}_{2}$ gas mixture. Environ Technol. 2015;36(1):106-14. 